\title{
Real-time aerosol optical properties, morphology and mixing states under clear, haze and fog episodes in the summer of urban Beijing
}

\author{
Rui $\mathrm{Li}^{1}$, Yunjie $\mathrm{Hu}^{1}$, Ling $\mathrm{Li}^{1}$, Hongbo $\mathrm{Fu}^{1,2}$, and Jianmin Chen ${ }^{1}$ \\ ${ }^{1}$ Shanghai Key Laboratory of Atmospheric Particle Pollution and Prevention, Department of Environmental Science \& \\ Engineering, Fudan University, Shanghai 200433, China \\ ${ }^{2}$ Collaborative Innovation Center of Atmospheric Environment and Equipment Technology (CICAEET), Nanjing University \\ of Information Science and Technology, Nanjing 210044, China
}

Correspondence to: Hongbo Fu (fuhb@fudan.edu.cn) and Jianmin Chen (jmchen@fudan.edu.cn)

Received: 3 November 2016 - Discussion started: 16 January 2017

Revised: 16 March 2017 - Accepted: 20 March 2017 - Published: 19 April 2017

\begin{abstract}
Elucidating the relationship between characteristics of aerosol particles and optical absorption is important to deepen the understanding of atmospheric chemistry. Aerosol particles play significant roles in climate forcing via their optical absorption properties. However, the relationship between characteristics of aerosol particles and optical absorption remains poorly understood. Aerosol optical properties and morphologies were measured by a transmission electron microscope (TEM), cavity ring-down spectrometer (CRDS), a nephelometer and an Aethalometer in a urban site of Beijing from 24 May to 22 June. Five episodes were categorized according to the meteorological conditions and composition. The results showed that the clear episode (EP-2 and EP-4) featured as the low aerosol optical depth $($ AOD $=0.72)$ and fewer pollutants compared with haze (1.14) and fog (2.92) episodes and the particles are mostly externally mixed. The high Ångström exponent (>2.0) suggests that coarse particles were scarcely observed in EP-2 due to the washout of a previous heavy rain, whereas they were widespread in EP-4 (Ångström exponent $=0.04$ ), which had some mineral particles introduced from the north. In contrast, industry-induced haze (EP-1) and biomass-burning-induced haze (EP-5) were both affected by the south air mass. Compared with the EP-2 and EP-4, the AOD values and the size distribution of particles during EP-1 and EP-5 were much greater because of relatively high particle concentrations. All of the particles were classified into nine categories, i.e. S-rich, N-rich, mineral, K-rich, soot, tar ball, organic, metal and fly ash, on
\end{abstract}

the basis of TEM analysis. In contrast to the EP-1, a large fraction of soot, which sticks to $\mathrm{KCl}$, sulfate or nitrate particles, was detected during EP-5. Additionally, evident enhancement of light absorption was observed during the EP-5, which was mainly ascribed to both black carbon (BC) acceleration and other absorbing substances. However, soot was found mostly internally mixed with sulfate and nitrate during a soot fog episode (EP-3), resulting in evident enhancement of light absorption. The larger size distribution was likely to be caused by both hygroscopic growth and collision between particles during the aging. About $28 \%$ of particles were internally mixed during the foggy days, which favoured the light absorption. The comparison of all the episodes provides a deeper insight into how mixing states influence the aerosol extinction properties and also a clue as to how to control air pollution in the crop burning seasons.

\section{Introduction}

Aerosol particles are ubiquitous in the troposphere and exert an important influence on global climate and the environment (Ramana et al., 2010). They affect climate through direct scattering, transmission, and absorption of radiation, or indirectly by acting as nuclei for cloud formation (Buseck and Posfai, 1999). In addition, light extinction by aerosol particles can impair visibility, both during extreme events such as dust storms and more widely in the vicinity of urban regions, 
frequently leading to regional haze and fog events (Wang et al., 2009a; Chameides et al., 1999; Sun et al., 2006; Saleh et al., 2016). Inorganic salts and light-coloured organic carbon have a "cooling effect" on the climate due to a decrease in the solar radiation that reaches the Earth's surface (Buseck and Posfai, 1999). Soot aerosols, mineral dust, and brown carbon are important absorbing aerosols that can lead to global and regional warming effects (Buseck and Posfai, 1999; Bahadur et al., 2012; Wang et al., 2014). The impact of aerosols on the Earth's climate is a major uncertainty in climate change models as was emphasized in the latest Intergovernmental Panel on Climate Change (IPCC) report (Solomon, 2007). It follows that understanding aerosol optical behaviour and associated spatial and temporal variability is a necessary prerequisite to understanding its role in climate and the environment (Langridge et al., 2012; Che et al., 2014). Soot is a major contributor to Earth's radiative balance (Ramana et al., 2010). Recent investigations involving direct atmospheric measurements of soot aerosols suggest that these aerosols may have a global warming potential second only to $\mathrm{CO}_{2}$, and the warming effect by soot nearly equals the net cooling effect of other anthropogenic aerosols (Jacobson, 2001). Not surprisingly, the importance of soot to climate change has been a major focus of many modelling, laboratory, and field studies (Zhang et al., 2008; Adler et al., 2010; Moffet and Prather, 2009; Adachi and Buseck, 2008; Ram et al., 2012). The main uncertainty stems from the fact that the actual amount soot that warms our atmosphere strongly depends on the manner and degree in which it is mixed with other species, a property referred to as mixing state (Jacobson, 2001; Moffet and Prather, 2009). The mixing state was found to affect the soot global direct forcing by a factor of 2.9. It has been shown that absorption by soot increases when soot particles are internally mixed and/or coated with other less absorbing materials (Moffet and Prather, 2009). This enhanced absorption in such structure is because of the lensing effect of coated materials (Jacobson, 2001). Field measurements indicate that during transport from the sources, fresh soot becomes internally mixed with sulfate and organics, leading to enhancement in light absorption, which was in agreement with the results of modelling calculation (Kleinman et al., 2007; Doran et al., 2007; Carabali et al., 2012). Kleinman et al. (2007) observed a doubling in the ratio of aerosol light absorption in aged air masses compared to fresh emissions over the eastern US. Similar increases in absorption by soot-bearing aerosol have been reported from ground site measurements performed at a series of locations downwind of Mexico City (Doran et al., 2007). Compiling both the surface and aircraft measurements, Ramana et al. (2010) recommended that the solar-absorption efficiency of the Beijing and Shanghai plumes was positively correlated with the ratio of soot to sulfate. Lei et al. (2014) further confirmed that the enhanced absorption of mixed aerosols depended upon hygroscopicity and the thickness of the coating. Based on the combined evidence from modelling and field studies, most researchers have proposed that internal mixing models of soot present more realistic absorption estimates as compared to external mixing models in which soot particles coexist with other particles in a physically separated manner (Jacobson, 2001; Ramana et al., 2010; Lei et al., 2014).

Biomass burning is by far the largest source of primary, fine carbonaceous aerosols in the atmosphere (Habib et al., 2008). It is estimated to contribute $20 \%$ of soot aerosols from biomass burning. Besides strongly absorbing soot particles, high amounts of brown organic carbon, such as "tar balls" or humic-like substances, can be emitted from biomass burning (Roden et al., 2006; Hand et al., 2005; Hoffer et al., 2006). Brown carbon has a significant absorbing component at short wavelengths that may be comparable to the soot absorption (Alexander et al., 2008; Bahadur et al., 2012). Consequently, organic carbon from biomass burning may also contribute to the warming potential of aerosols (Alexander et al., 2008). These large quantities of climate-related aerosols can persist in the atmosphere for several weeks and be transported over long distances. As a result, biomass burning aerosols have a significant impact on climate, which was considered to provide a major uncertainty in accurately predicting the effects of light-absorbing aerosols on the climate (Bahadur et al., 2012). Many field measurements in East Asia, South Asia and Africa have shown extensive biomass burning in these regions causes important perturbations in the Earth's atmosphere (Gustafsson et al., 2009; Alexander et al., 2008; Hand et al., 2005). Once biomass burning particles are mixed with other atmospheric components during aging and transport, such as sulfate and dust, solar absorption is further amplified due to the formation of internally mixed particles (Ramanathan et al., 2005). Such mixtures of absorbing and scattering aerosols at the regional scale are referred to as "ABCs" (abbreviated from "atmospheric brown clouds") (Ramanathan et al., 2007). ABCs' radiative forcing can cool the surface, stabilize the atmosphere, and reduce evaporation and monsoonal rainfall. The large influence of ABCs on the climate and hydrological cycle changes has recently been demonstrated through model simulations (Ramanathan et al., 2005, 2007).

In the farmlands of eastern China such as those near Beijing, most wheat straw is burned in the field within 1 week after harvesting in preparation for rice cultivation during May and June. Emissions from the biomass burning are often transported and mixed with urban pollution, leading to degradation of air quality, impairment of visibility, and regional haze events (Li et al., 2010). Stagnation occurs during episodes of urban haze, when there is insufficient wind velocity to carry pollutants away from the city (Katrinak et al., 1993; Sun et al., 2006). During these periods of pollutant retention, haze particles aggregate, continue to collide and combine, resulting in larger average sizes and altered morphology (Li et al., 2010). Enhanced absorption is mainly brought about in the presence of high levels of non-absorbing hygroscopic aerosols such as sulfates, nitrates, and water- 
soluble organic carbon, as their hygroscopic nature favours internal mixing/core-shell formation (Bahadur et al., 2012). On the other hand, under the conditions of high atmospheric relative humidity $(\mathrm{RH})$, the initially hydrophobic soot particles can become associated with hygroscopic materials, leading to increased scattering due to particle growth. In an extreme case, the coating material can cause the absorbing fractal soot to collapse, potentially changing optical behaviour, which further complicates this picture (Zhang et al., 2008; Langridge et al., 2012; Lei et al., 2014; Tan et al., 2016). Such changes cause both positive and negative effects on the interplay between the direct and indirect aerosol effects, making overall prediction of the radiative forcing difficult. At present, large uncertainties exist in estimates of the radiative forcing of haze particles because of the lack of detailed in situ measurements of the mixing state and the associated optical properties as a function of particle size and composition (Moffet and Prather, 2009). These uncertainties limit our ability to quantify the relative impacts of soot on climate, thus limiting our ability to make effective policy decisions.

In an attempt to address this knowledge gap, and in the absence of the opportunity for widespread field studies in eastern China, the experiments in this study were designed to simultaneously measure mixing states and optical properties of haze particles. The present analysis focused on the Beijing plume, which in addition to strong urban emissions is influenced by local agricultural emissions ( $\mathrm{Li}$ et al., 2010). The light extinction and scattering coefficients were measured with a cavity ring-down spectrometer (CRDS) and a nephelometer, respectively. Absorption was calculated from the difference between extinction and scattering. Individual aerosol particles were identified with transmission electron microscopy (TEM). Back trajectory analyses suggest flow patterns consistent with long-range transport of agricultural smoke to the study site during periods when the sampling site was engulfed in severe haze and fog.

\section{Experimental sections}

\subsection{Site description}

All of the ambient investigations of aerosol optical properties and TEM samplings were conducted at the Institution of Atmospheric Physics $\left(39^{\circ} 58^{\prime} \mathrm{N}, 116^{\circ} 22^{\prime} \mathrm{N}\right)$, Beijing, China, from 24 May to 22 June 2012. Samplers were mounted on the roof of a two-storey building about $8 \mathrm{~m}$ above ground level. The surroundings are in the convergence of residential and commercial zones, with some steel plants located in the area at a distance of 6 to $25 \mathrm{~km}$ and a waste incineration facility (Gaodun) $8 \mathrm{~km}$ to the northeast, which has an operational capacity of $1600 \mathrm{t} \mathrm{d}^{-1}$. In addition, the sampling site is situated in the middle of the North Third Ring Road and North Fourth Ring Road, approximately $360 \mathrm{~m}$ south and $380 \mathrm{~m}$ north of the site, respectively. The sampling site is impacted by the mixture of emissions from residential and industrial areas as well as waste combustion and vehicles, but it is not dominated by any one source.

\subsection{Cavity ring-down spectrometer and nephelometer}

A in-house-designed cavity ring-down spectrometer (CRDS) was used to measure the extinction coefficient of aerosols at 1 min intervals with an accuracy of $0.1 \mathrm{Mm}^{-1}$. Aerosols were dried by diffusion drying tubes before they reached CRDS and nephelometer to exclude the influence of relative humidity $(\mathrm{RH})$ on the aerosol optical properties. RH was kept below $40 \%$ to minimize the effects of changing $\mathrm{RH}$ on measurements. The cavity was formed by two high-reflectivity dielectric mirrors (Los Gatos Research, Inc., Mountain View, CA, USA) and a stainless steel cell equipped with an outlet at each end and one in the middle. The distance between the two mirrors is $76.4 \mathrm{~cm}$, while the filling length is $58.0 \mathrm{~cm}$. Dry nitrogen was released near the mirrors at a flow of $0.03 \mathrm{~L} \mathrm{~min}^{-1}$ to prevent the contamination of mirrors and aerosol flow was set $1.0 \mathrm{~L} \mathrm{~min}^{-1}$. The $532 \mathrm{~nm}$ light pulse (energy $100 \mu \mathrm{J}$, duration $11 \mathrm{~ns}$ ) was generated by a Qswitched pulsed laser (CrystaLaser QG-532-500). Leaking light through the mirrors was monitored by a Hamamatsu R928 photomultiplier. Details about the system are reported in $\mathrm{Li}$ et al. (2011). To calculate the decay time, 1000 ringdown traces were averaged at a $1000 \mathrm{~Hz}$ repetition rate. The extinction coefficient $\left(\alpha_{\text {ext }}\right)$ has an uncertainty below $3 \%$ under controlled conditions. It was calculated according to the following equation:

$\alpha_{\mathrm{ext}}=\frac{L}{l c}\left(\frac{1}{\tau}-\frac{1}{\tau_{0}}\right)$,

where $L$ is the length of the cavity, $l$ is effective length occupied by particles, $c$ is the speed of light, $\tau_{0}$ is ring time of the cavity filled with particle-free air and $\tau$ is the calculated decay time (Li et al., 2011).

An integrating nephelometer (TSI, model 3563) was operated to obtain aerosol scattering coefficient at three different wavelengths $(450,550$, and $700 \mathrm{~nm})$ and the flow rate was set at $5 \mathrm{~L} \mathrm{~min}^{-1}$. During the field campaign, a zero check was done automatically by pumping in particle-free air for 5 min once every $2 \mathrm{~h}$, and a span check was conducted manually using $\mathrm{CO}_{2}$ as the high span gas and filtered air as the low span gas every week. RH was kept below $40 \%$ to minimize the effects of changing RH on measurements (Peppler et al., 2000; Clarke et al., 2007). The raw data were corrected for truncation errors and a non-Lambertian light source using Ångström exponents $(\AA)$ according to Anderson and Ogren (1998) (Anderson and Ogren, 1998). Generally, the total uncertainty in the scattering coefficient $\left(\alpha_{\text {scat }}\right)$ was below $10 \%$. In accordance with the extinction coefficient at $532 \mathrm{~nm}$, the scattering coefficients was converted to 
$532 \mathrm{~nm}\left(\alpha_{\text {scat,532}}\right)$ on the basis of the following equation:

$\alpha_{\text {scat }, 532}=\alpha_{\text {scat }, \lambda}\left(\frac{532}{\lambda}\right)^{-\AA}$,

where $\alpha_{\text {scat }, \lambda}$ is the scattering coefficient at the wavelength of $\lambda$. Accordingly, Å could be calculated as the Eq. (3),

$\AA=-\frac{\lg \left(\alpha_{\text {scat }, \lambda_{1}} / \alpha_{\text {scat }, \lambda_{2}}\right)}{\lg \left(\lambda_{1} / \lambda_{2}\right)}$,

and the single-scattering albedo $\left(\omega_{0}\right)$ at the given wavelength could be calculated from Eq. (4),

$\omega_{0}=\frac{\alpha_{\text {scat }}}{\alpha_{\text {ext }}}$.

The sum of absorption $\left(\alpha_{\mathrm{abs}}\right)$ and scattering $\left(\alpha_{\text {ext }}\right)$ coefficients equals the extinction coefficient $\left(\alpha_{\text {scat }}\right)$, which could be derived from the Eq. (5),

$\alpha_{\mathrm{abs}}=\alpha_{\mathrm{ext}}-\alpha_{\text {scat }}$.

It is known that $\mathrm{RH}$ also has a profound impact on visibility (Chow et al., 2002); however, in this study the aerosols passed through a diffusion drying tube before the measurement of optical properties, and thus aerosol optical property measurements and TEM observations were both performed under dry conditions.

\subsection{Aethalometer}

An Aethalometer (model AE-31, Magee Scientific) was employed to simultaneously quantify BC concentration by calculating the optical attenuation (absorbance) of light from light-emitting diode lamps emitting at seven different wavelengths $(370,470,520,590,660,880$ and $950 \mathrm{~nm})$ every $5 \mathrm{~min}$, with a typical half-width of $0.02 \mu \mathrm{m}$ (Hansen, 2003). The flow rate was set to be $5 \mathrm{~L} \mathrm{~min}^{-1}$ and a clean filter canister in the inlet was used weekly to conduct the zero calibration. A PM 2.5 cyclone (BGI SCC 1.828) was employed in the sampling line with a flow rate of $5 \mathrm{~L} \mathrm{~min}^{-1}$. A typical noise level is less than $0.1 \mu \mathrm{g} \mathrm{cm}^{-3}$ on a $5 \mathrm{~min}$ basis. Two photo-detectors monitor the light intensity as a function of time. One measured the light intensity of the light crossing the reference quartz filter, while the other measured that of the same light crossing a sample spot under identical conditions. The wavelength at $880 \mathrm{~nm}$ was used to derive the aerosol absorption coefficient $\left(\sigma_{\text {abs }}\right)$. Then BC concentration could be converted under the assumption that the $\mathrm{BC}$ mass concentration $[\mathrm{BC}]$ on the filter was linearly correlated with the aerosol absorption coefficient, as in the following equation:

$\sigma_{\mathrm{abs}}=\alpha[\mathrm{BC}]$,

where $[\mathrm{BC}]$ is the $\mathrm{BC}$ mass concentration, and $\alpha$ is a conversion factor. A factor of $8.28 \mathrm{~m}^{2} \mathrm{~g}^{-1}$ was employed to convert the aerosol absorption coefficient to $\mathrm{BC}$ concentration, according to the results of inter-comparison experiment conducted in south China (Wu et al., 2009; Yan et al., 2008).

The uncertainty in measurement might originate from the multiple scattering in the filter fibres in the unloaded filter and in those particles embedded in the filters (Clarke et al., 2007; Jeong et al., 2004). The attenuation values were within the limit of an acceptable uncertainty, that is, no greater than 150 in the range of 75-125 at various wavelengths, verifying the reliability of the measurement. Moreover, the BC concentration was compared with the results of a multi-angle absorption photometer (MAAP, model 5012) and a particle soot absorption photometer (PSAP, Radiance Research), which shows great consistence.

\subsection{Aerosol optical depth}

Aerosol optical depth (AOD) data at the sampling site were based on the MODIS (Moderate Resolution Imaging Spectroradiometer) retrieved data from a CIMEL CE-318 sun photometer (AERONET/PHOTONS) at the Institute of Atmospheric Physics, reflecting the amount of direct sunlight prevented from reaching the ground by aerosol particles, by measuring the extinction of the solar beam. The AOD value of the sampling site was downloaded from the AERONET website (http://aeronet.gsfc.nasa.gov), using the level 2.0 quality-assured data. These data are pre- and postfield-calibrated, automatically cloud-cleared and manually inspected. The regional distribution of AOD was obtained from Giovanni (GES-DISC Interactive Online Visualization And Analysis Infrastructure) maps from MODIS satellite data (http://disc.sci.gsfc.nasa.gov/giovanni). Two continuous episodes categorized as clear and haze are chosen: 23 to 27 May and 19 to 27 June, respectively.

\subsection{TEM analysis}

Samples were made by collecting airborne particles onto copper TEM grids coated with carbon film (carbon type-B, 300-mesh copper, Tianld Co., China) using a single-stage cascade impactor with a $0.5 \mathrm{~mm}$ diameter jet nozzle at a flow rate of $1.0 \mathrm{~L} \times \mathrm{min}^{-1}$. According to the visibility, the sampling time varies from 1 to $10 \mathrm{~min}$. Three or four samples were collected each morning at around 08:00 and also each time when haze or fog appeared. After collection, samples were stored in a dry plastic box sealed in a plastic bag and kept in a desiccator at $25^{\circ} \mathrm{C}$ and $20 \pm 3 \% \mathrm{RH}$. Details of the analysed samples, such as sampling time and instantaneous meteorological state, are listed in Table 1.

Individual aerosol samples were analysed using a highresolution TEM (JEOL 2010, Japan) operated at $200 \mathrm{kV}$. TEM can obtain morphology, size, and mixing state of individual aerosol particles. Energy-dispersive X-ray spectrometer (EDS) can get the chemical compositions of the targeted particles. $\mathrm{Cu}$ and $\mathrm{C}$ were excluded from the copper TEM grid with carbon film. Details have been described in previous pa- 
Table 1. Sampling time and instantaneous meteorological state.

\begin{tabular}{|c|c|c|c|c|c|c|c|c|c|}
\hline \multicolumn{3}{|c|}{ Sampling time $\left(\mathrm{BST}^{\mathrm{a}}\right)$} & \multirow[t]{2}{*}{ Conditions } & \multirow{2}{*}{$\begin{array}{l}\text { RH } \\
(\%)\end{array}$} & \multirow{2}{*}{$\begin{array}{l}\text { Temp. } \\
\left({ }^{\circ} \mathrm{C}\right)\end{array}$} & \multicolumn{2}{|c|}{ Wind } & \multirow{2}{*}{$\begin{array}{r}\text { Visibility } \\
(\mathrm{km})\end{array}$} & \multirow[t]{2}{*}{ No. } \\
\hline Date & Starting & Duration & & & & $\begin{array}{r}\text { Speed } \\
\left(\mathrm{m} \mathrm{s}^{-1}\right)\end{array}$ & $\begin{array}{r}\text { Direction } \\
\left({ }^{\circ}\right)\end{array}$ & & \\
\hline $25-05-2012$ & $13: 40$ & $4 \mathrm{~min}$ & Clear & 20 & 29 & 2 & 160 & - & 136 \\
\hline $30-05-2012$ & $09: 31$ & $16 \mathrm{~min}$ & Clear & 29 & 24 & 7 & 350 & - & 92 \\
\hline 02-06-2012 & 09:00 & $1 \mathrm{~min}$ & Mist $^{b}$ & 83 & 20 & 4 & 180 & 2 & 146 \\
\hline $02-06-2012$ & $13: 27$ & $2 \mathrm{~min}$ & Clear & 48 & 27 & 4 & 190 & - & 138 \\
\hline 03-06-2012 & $10: 13$ & $15 \mathrm{~s}$ & Fog & 88 & 22 & 1 & variable & 1.2 & 110 \\
\hline $18-06-2012$ & $18: 52$ & $2 \mathrm{~min}$ & Haze & 55 & 29 & 3 & 140 & 3 & 172 \\
\hline 19-06-2012 & 09:10 & $2 \mathrm{~min}$ & Haze & 61 & 25 & 1 & variable & 2.8 & 120 \\
\hline $21-06-2012$ & 09:10 & $1 \mathrm{~min}$ & Haze & 69 & 26 & 2 & 110 & 2.2 & 117 \\
\hline $23-06-2012$ & $12: 45$ & $2 \min$ & Mist $^{b}$ & 84 & 25 & 4 & 120 & 3 & 142 \\
\hline
\end{tabular}

${ }^{a}$ Beijing standard time (GMT -8$) .{ }^{b}$ Mist is studied here as fog.

pers (Fu et al., 2012; Guo et al., 2014a). Particle sizes on the grid decrease from the centre to the periphery due to the limitation of sampler, and three to four round meshes were chosen from the centre to the periphery in a line to ensure the representativeness of the entire size range. Each mesh analyses three to four views. The average values of each mesh were used for statistics. The analysis was done by labourintensive manual sorting of the particles. Nine grids, with a total of 1173 particles, have been analysed by TEM.

\subsection{Back trajectories and meteorological data}

The NOAA/ARL Hybrid Single-Particle Lagrangian Integrated Trajectory model (available at http://www.arl.noaa. gov/ready/hysplit4.html) was employed to determine back trajectories arriving at Beijing at $100 \mathrm{~m}$, employing the data of Global Data Assimilation System (GDAS). Each trajectory represented the past $72 \mathrm{~h}$ of the air mass, with its arrival time at 00:00 UTC every day.

Meteorological data were downloaded from Weather Underground (www.wunderground.com), and daily $\mathrm{PM}_{10}$ values were transformed from daily API (air pollutant index) in the data centre of the Ministry of Environmental Protection of the People's Republic of China (http://datacenter.mep.gov. $\mathrm{cn} /)$.

\section{Results and discussion}

\subsection{Episode segregation}

Haze is usually defined as a weather phenomenon that lasts at least $4 \mathrm{~h}$ when the visibility is less than $10 \mathrm{~km}$ and $\mathrm{RH}$ is lower than $80 \%$ (Sun et al., 2006), while fog was characterized with a higher RH, larger than $90 \%$, according to the Chinese Meteorological Administration. The sampling period was categorized into 5 episodes to observe the opti- cal properties between different weather phenomena (Fig. 1). Although every episode contains a mixture of different types of pollution, the main origin can be discerned by studying the weather conditions, back trajectories and fire maps. The first episode (EP-1) was from 24 to 29 May, when a haze event occurred with the south wind bringing in the industrial pollution from the heavily polluted cities in the south, which conformed to the 3-day back trajectories shown in Fig. 2a, showing the air masses passing through Henan, Shandong, Hebei and Tianjin before arriving at the sampling site. Only scattered fire spots were observed during these days along the air mass pathway, suggesting little biomass burning emission interference. The second episode (EP-2) was in clear weather on 30 May. A heavy rain interrupted the previous haze; hence the air was cleaned up by rain washout. It was impacted by the air mass from the north region (Fig. 2b) as the air parcel from the north was relatively clean and the time was insufficient for a heavy accumulation. This episode could be viewed as the background. The third episode (EP-3) from 31 May to 9 June was changeable, with a variety of transitions between fog, haze and clear days. This was partly caused by the variable wind directions and air mass transference (Fig. 2c). When the wind is from the east, the back trajectories are across the Bohai Sea, and the air mass carries a high content of water vapour, facilitating the formation of fog, whereas when southerly wind is dominant, haze is likely to occur (Wang and Chen, 2014; Zhang et al., 2010). The following fourth episode (EP-4) from 10 to 16 June consists mainly of clear days with a small amount of dust. The dust's back trajectories originate from the north part (Fig. 2d), mostly travelling from the Siberian region, across eastern Mongolia and Inner Mongolia and finally arriving at the sampling site with little pollution. The last episode (EP-5) was from 17 to 21 June. Severe haze was observed during this time. Figure 2e shows that the air parcel pathway crossed dense fire spots, indicating a severe impact of the biomass 


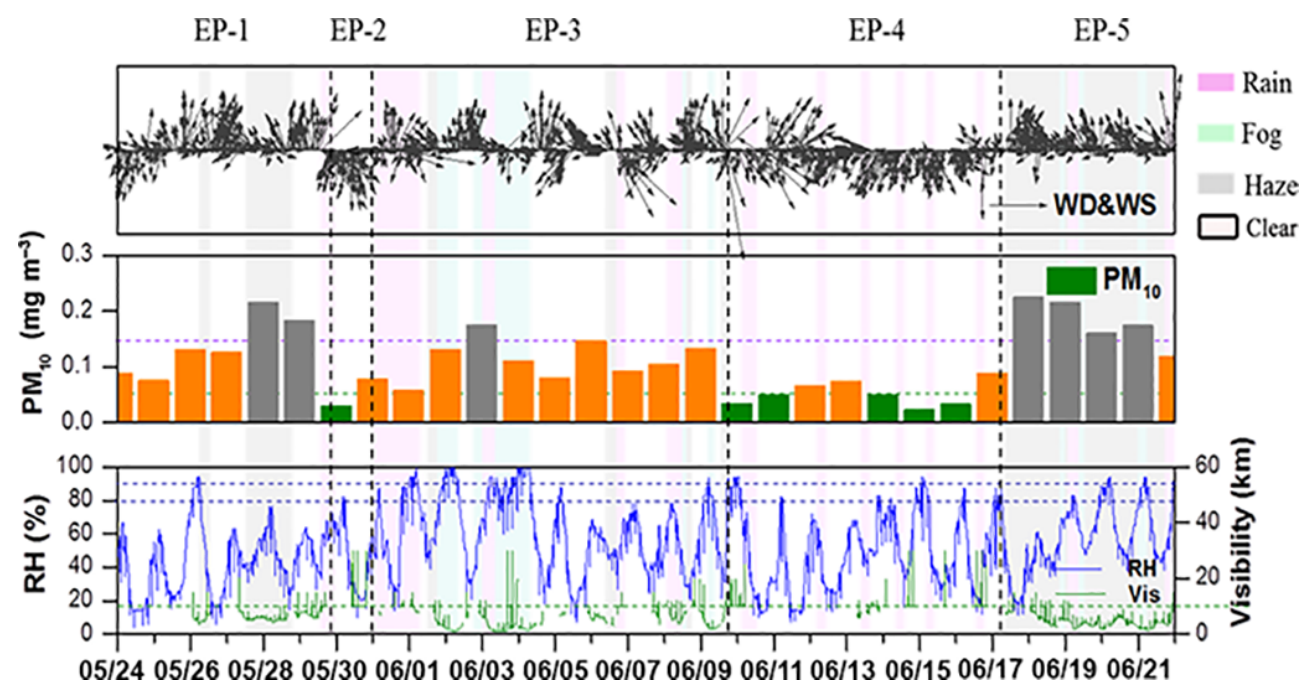

Figure 1. Categorization of five episodes. EP-1 features haze caused mainly by transportation of southern industrial pollution; EP-2 is clear, EP-3 has a frequent transition among haze, fog and clear conditions; EP-4 is mainly clear with rain interrupting; and EP-5 haze resulted mainly from the biomass burning (brown, green, and orange colours mean the haze, clear, and fog conditions, respectively).

burning. Every year after harvest, crop residue burning is extremely frequent in Anhui, Shandong and Henan provinces, which serve as important centres for the rice supply (Li et al., 2010). Therefore, the biomass burning emissions can be the main contributor to the haze formation in this episode.

\subsection{Variation in aerosol optical characters}

Aerosol optical depth (AOD) is representative of the airborne aerosol loading in the atmospheric column, which was also verified by a significant related coefficient with $\mathrm{PM}_{10}$ $(r=0.603)$ (Fig. 1). The overall AOD is contributed by both Mie scatter and Rayleigh scatter (Fig. 3a). The former one is produced by the scatter effect of particles, while the latter one by gases (Brown et al., 2014). The data shown in Fig. 1 demonstrate that gas plays a negligible role in the AOD value, especially when aerosol loading is high. The AOD value seemed to vary with the weather transition. During the clean days, the mean AOD was 0.723 , while it became higher when the haze and fog were formed, with a mean value of 2.92 and 1.14 , respectively. During the measurement period, AOD reached its highest value of 5.0 in the hazy EP-5, which is more than 5 times higher than the average AOD of 0.95 in Beijing measured from March 2012 to February 2013 (Guo et al., 2014b). Such high AOD could be attributed to the pollutant accumulation, especially biomass burning emission from the crop combustion.

Ångström exponent $(\AA)$ is a good indicator of aerosol size distribution, which decreases with the increase in particle size (Eck et al., 1999). The value is computed from pairs of AOD measurements at $700 \mathrm{~nm}$ with $450 \mathrm{~nm}, 700 \mathrm{~nm}$ with $550 \mathrm{~nm}$ and $550 \mathrm{~nm}$ with $450 \mathrm{~nm}$, respectively. A high accordance is observed between each pair (Fig. 3b). The $\AA$ in- creases sharply to its highest value above 2.0 at EP-2, 45 times of the minimum value 0.044 observed in EP-5. This could be explained by the wet removal impact of the heavy rain. It is well known that rains wash out the coarse particles, resulting in a fine size distribution (Dey et al., 2004). The $\AA$ value during EP-4 fluctuated between 0.08 and 0.2. Since the rains are light and short, the clear days in EP-4 are more impacted by the northern air mass, which brings in a larger fraction of coarse dust particles. Comparatively, the $\AA$ value was lower in both the haze and fog periods, including EP1, EP-3 and EP-5. Especially in the case of EP-5, the low $\AA$ value indicated that the biomass burning emission could contain more coarse particles. Such a scene is in contrast to the conclusion that the haze days were dominated by fine particles (Yan et al., 2008). It is likely caused by the high collision occurrences of fine particles along the long-range transport from the fire spots (Wang et al., 2009b). In comparison, the $\AA$ value during 2001 to 2005 in Beijing varied from between 0.04 and 1.06 (Yu et al., 2006). The lower limit is similar to the present field measurement, while the upper limit is much higher than this study. This could be attributed to the increase in fine particle emission contributed by more vehicles, waste incineration and industrial plants in the past years.

Single-scattering albedo (SSA), $\omega$, was defined as the ratio of the aerosol scattering coefficient $\left(\sigma_{\mathrm{sca}}\right)$ to the extinction coefficient $\left(\sigma_{\text {ext }}\right)$. This parameter is especially important in the estimation of direct aerosol radiative forcing, since even a small error in its estimation might change the sign of aerosol radiative forcing (Takemura et al., 2002). Figure $3 \mathrm{c}$ and d show the time series of $\sigma_{\mathrm{sca}}, \sigma_{\mathrm{abs}}, \sigma_{\mathrm{ext}}$ and SSA at $550 \mathrm{~nm}$ during the measurement period. The mean $\omega$ was $0.73,0.82$ and 0.79 in EP-2, EP-4, and EP-5, respectively, implying that mineral dust in EP-4 accelerates the optical scattering, while 

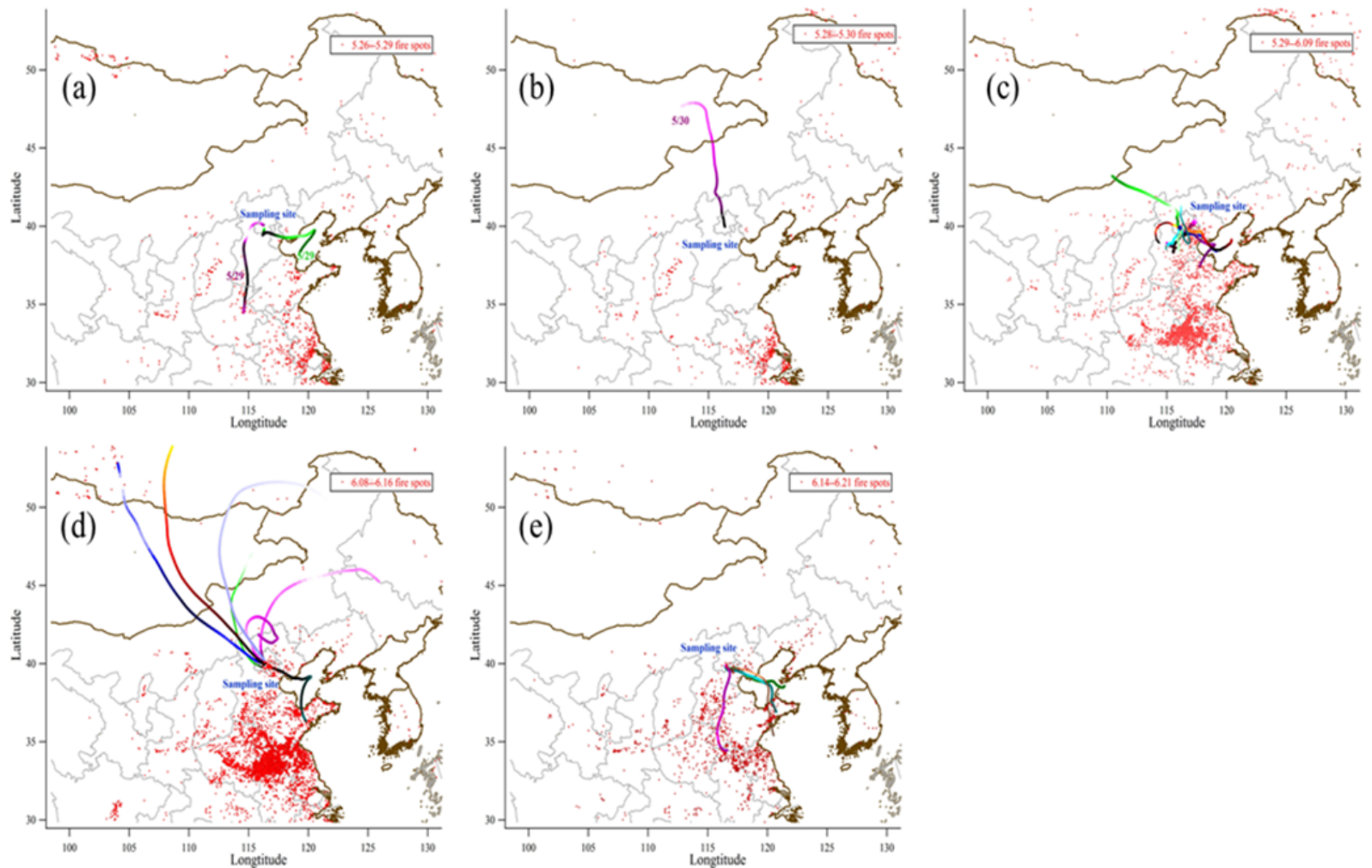

Figure 2. The 3-day back-trajectory clusters of each episode, arriving at Beijing at the height of $100 \mathrm{~m}$, together with the fire spot distribution of these periods (green, purple, red, and blue lines denote the air parcel with the height of 500, 1000, 2000, and 3000 m).

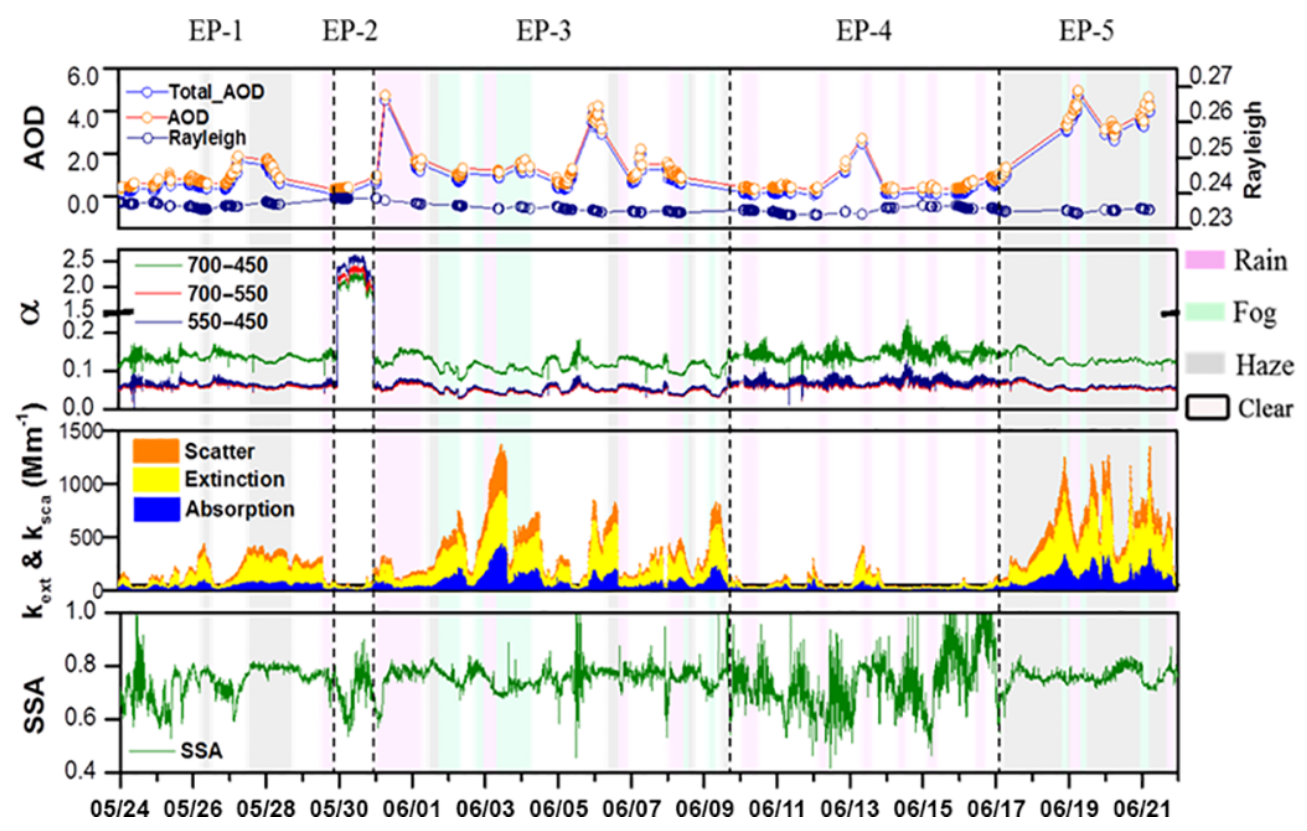

Figure 3. Variation in optical parameters during the study period. (a) Total aerosol optical depth (AOD), and AOD resulting from Mie scatter and Rayleigh scatter; (b) Ångström exponent ( $\AA$ ) computed from the pairs of 700 and $450 \mathrm{~nm}, 700$ and $550 \mathrm{~nm}$, and 550 and $450 \mathrm{~nm}$; (c) light extinction, absorption and scattering coefficients; (d) calculated single-scattering albedo (SSA).

soot favours the optical absorption. Compared with other re-

ported results (Che et al., 2014; Li et al., 2007; Qian et al., 


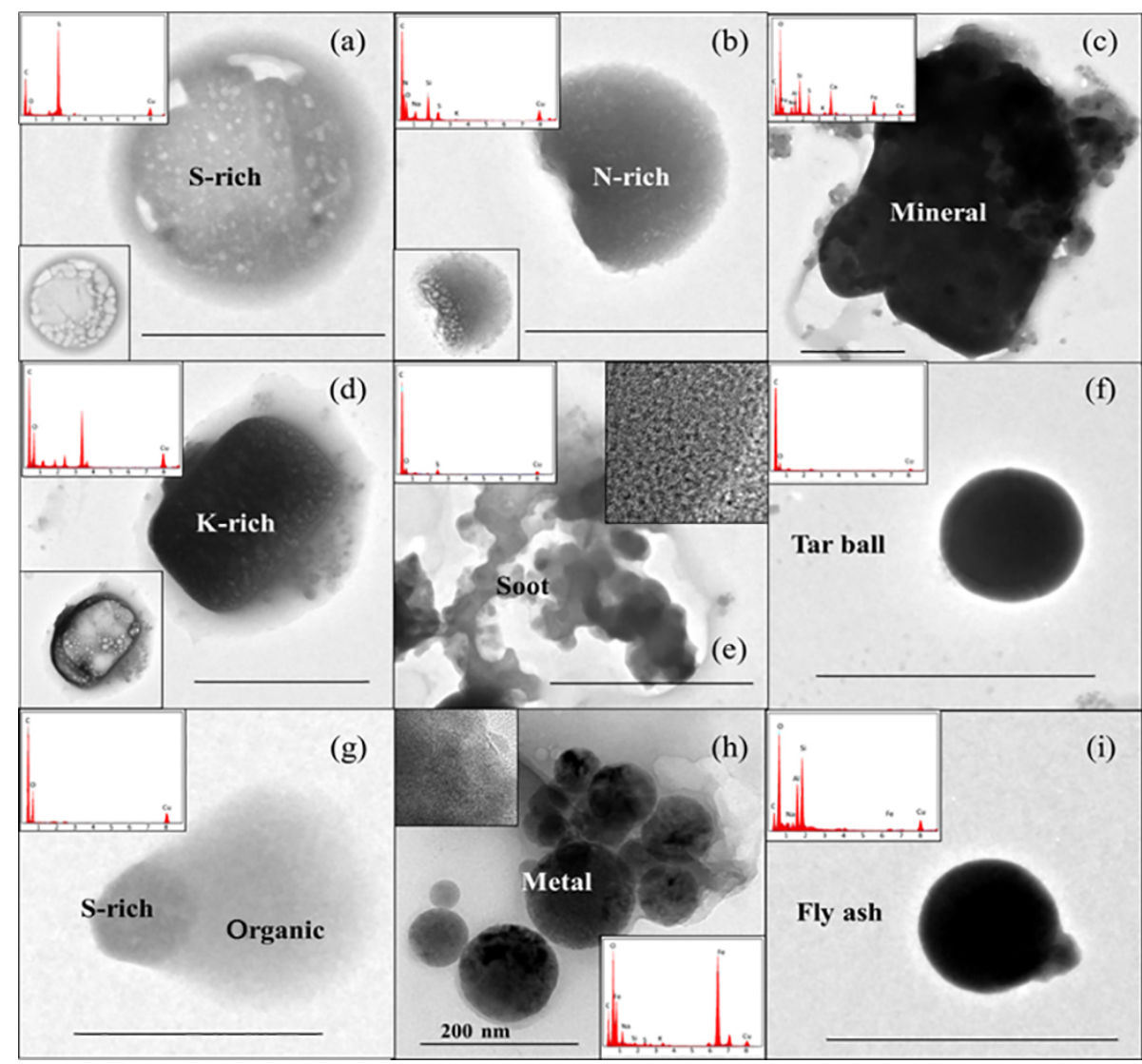

Figure 4. Nine categories of particles under the TEM view. The inserted spectra are obtained by the EDS, and the grid-like images are acquired from the selected-area diffraction. (a) S-rich, (b) N-rich, and (c) mineral. (d) K-rich, (e) soot, (f) tar ball, (g) organic, (h) metal, and (i) fly ash.

2007), the mean $\omega$ is lower in this study, suggesting that more soot is emitted into the atmosphere during this period. It is well known that soot emission is much higher in the past years, mainly contributed by the residential coal combustion, biomass burning, coke production, and diesel vehicles (Wang et al., 2012b). In particular, when air masses moved from the south, the sampling site was influenced by heavily polluted air mass mixed with soot, sulfate, and organic carbon components, from the dense population centres and industrial areas (Sun et al., 2006; Wang et al., 2006), which was also confirmed by the TEM observation.

\subsection{Morphology and chemical composition of aerosols}

Based on morphology and chemical composition, 1173 particles were classified into nine categories: S-rich (Fig. 4a), N-rich (Fig. 4b), mineral (Fig. 4c), K-rich (Fig. 4d), soot (Fig. 4e), tar ball (Fig. 4f), organic (Fig. 4g), metal (Fig. 4h) and fly ash (Fig. 4i). The classification is similar to the work reported by Li and Shao (2009).

The most common particles are sulfates and nitrates (Fig. 4a and b), which are around $1.0 \mu \mathrm{m}$ in size, and have a light-scattering ability (Jacobson, 2001). Sulfates appeared as subrounded masses under the TEM, which decomposed or evaporated under electron beam exposure. Conventionally, they were formed by the reaction of precursor $\mathrm{SO}_{2}$ or $\mathrm{H}_{2} \mathrm{SO}_{4}$ with other gases or particles (Khoder, 2002). Nitrates were mostly of "scalloped" morphology in the TEM images. They were relatively stable when exposed to the electron beam. Nitrates formed through the homogeneous reaction with the precursor $\mathrm{NO}_{2}$ or heterogenic reaction with $\mathrm{HNO}_{3}$ (Khoder, 2002) (Pathak et al., 2004; Seinfeld and Pandis, 2012).

On the clear days, as the result of effects of northern air mass, dust particles were relatively abundant. The size of dust particles (Fig. 4c) was large, usually bigger than $1.0 \mu \mathrm{m}$, and up to $8.0 \mu \mathrm{m}$. Their compositions differed from each other, mostly silicates and calcium sulfate or carbonate, all of which were stable under the exposure to the electron beam. Dust particles were reported to have a light-scattering effect, resulting in a negative aerosol radiative forcing (Wang et al., 2009b). They took up a large portion in EP-4, impacted by the northerly wind taking along particles from the dusty regions.

As for the haze episode, K-rich particles (Li et al., 2010; Duan et al., 2004; Engling et al., 2009), soot (Li et al., 2010), 
tar balls (Chakrabarty et al., 2010; Bond, 2001) and organics (Lack et al., 2012) were more observed under the TEM. Krich particles (Fig. 4d) often existed as sulfate or nitrate. A larger fraction of K-rich particles was observed in EP-5 than in the other periods. Together with the back trajectories and fire spot maps, it was supposed that the regional haze that occurred in EP-5 was contributed significantly by biomass burning. K-rich particles were characterized by the irregular shape, which was unstable when exposed to the electron beam. $\mathrm{KCl}$ was barely detected in the samples, even though it has been recommended that $\mathrm{KCl}$ was internally mixed with $\mathrm{K}_{2} \mathrm{SO}_{4}$ and $\mathrm{KNO}_{3}$ in fresh biomass burning plumes (Li et al., 2010, 2003; Adachi and Buseck, 2008). Based on the EDS data, K-rich particles in the present work mostly consisted of $\mathrm{N}, \mathrm{Na}, \mathrm{O}, \mathrm{S}$, and $\mathrm{K}$, whereas it was free of $\mathrm{Cl}$, implying that $\mathrm{KCl}$ could have suffered from chemical reactions and transformed into sulfates or nitrates (Li and Shao, 2010). Such particles displayed a negative climate forcing (Hauglustaine et al., 2014).

It is well documented that soot (Fig. 4e) is vital to light absorption, which could alter regional atmospheric stability and vertical motions, large-scale circulation and precipitation with significant regional climate effects (Ramanathan et al., 2001; Jacobson, 2002). It was well characterized by a structure like an onion ring, resembling a fractal long chain as agglomerates of small spherical monomers ( $\mathrm{Li}$ and Shao, 2009). The fresh soot was loose and externally mixed. However, after undergoing long-range transportation and aging in the atmosphere, soot became more compacted, with a slight increase in $\mathrm{O}$ concentration because of the photochemistry (Stanmore et al., 2001; Krasowsky et al., 2016). Meanwhile, soot generally attached to other particles on the surface or serves as the core for the formation of other particles.

Tar balls (Fig. 4f) were present as spherical carbon balls with a small fraction of $\mathrm{O}$. These were thought to originate from smouldering combustion and have relatively strong absorption effects (Chakrabarty et al., 2010; Bond, 2001). Tar balls constituted a large fraction of the freshly emitted wildfire carbonaceous particles (China et al., 2013; Lack et al., 2012). However, they were seldom observed in the present work, even in EP-5, when there was severe biomass burning emission, which may be due to the difference in burning species and conditions.

Organic matter (Fig. 4g) identified by high-resolution TEM was an amorphous species, and was stable under the strong electron beam exposure. It could be traced to direct emission such as biomass burning (Lack et al., 2012) or to the second reaction between volatile organic compounds with ozone (Wang et al., 2012a). It can absorb radiation in the low visible and UV wavelengths (Chakrabarty et al., 2010; Clarke et al., 2007; Lewis et al., 2008; Hoffer et al., 2006). In addition, when attaching to soot as the core, organic matter can enhance absorption by internal mixing (Adachi and Buseck, 2008).

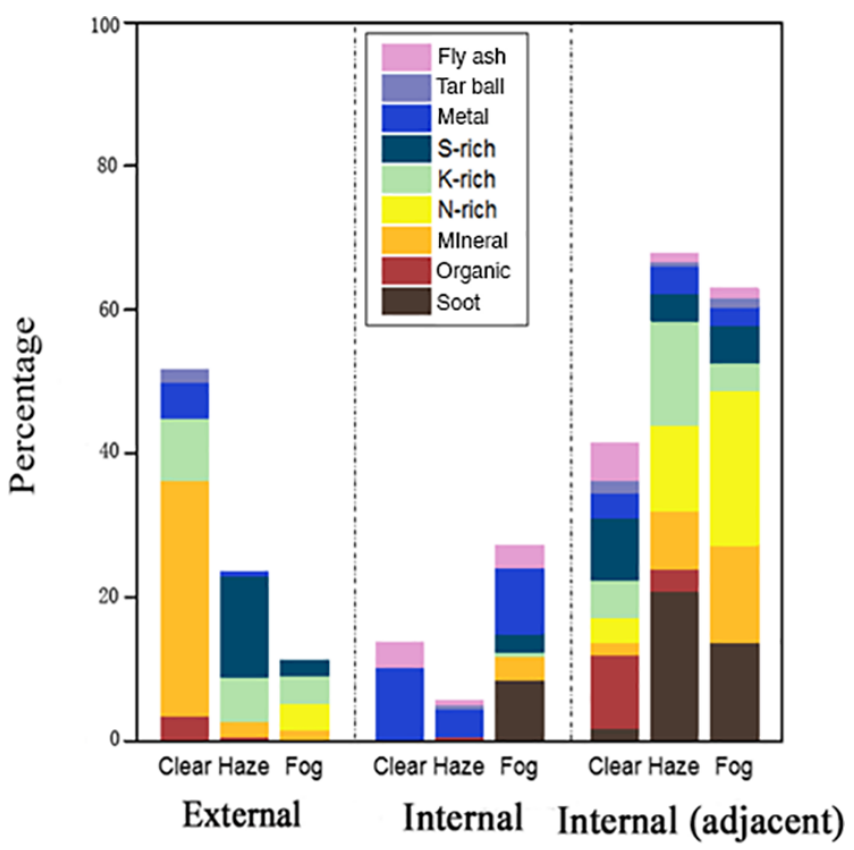

Figure 5. Percentages of nine particle components under clear, haze and fog conditions with different mixing states.

For the common haze and fog episodes, stagnated weather favours the accumulation of pollutants, especially metal particles and fly ash (Hu et al., 2015). Metal particles (Fig. 4h) were generally round and stable under the TEM. Fly ash (Fig. 4i) was a dark sphere with a large size of $>1 \mu \mathrm{m}$. It was a common product of industrial activities in northern China (Shi et al., 2003). As the complex refractive index (CRI) indicated, metal oxide particles and fly ash can scatter light, but the former has a weak absorption ability while the latter has almost no light absorption ability (Ebert et al., 2004).

Figure 5 shows the percentage of nine components in clear, haze and fog episodes under external mixing, internal mixing and adjacent states (partially internal mixing). About $28 \%$ of particles were internally mixed during the foggy days, while about $52 \%$ of particles exhibited external mixing state on clear days based on the TEM analysis. Mineral particles were likely to be externally mixed with K-rich particles and organic matter on clear days, while the external ratio of other particles was relatively lower, particularly during the haze and fog days. Li et al. (2010) showed that mineral particles generally displayed external association with organic matter or other particles. However, many fine particles including metal-bearing particles, fly ash and soot were often internally mixed with S-rich and K-rich particles, particularly during the fog-haze episodes. Shi et al. (2008) reported that rapid aging of fresh soot tended to appear during the fog-haze days, which were generally associated with ammonium sulfate. Heavily polluted air generally promoted the coagulation between S/K-rich particles and fine particles such as those of metal, soot, and fly ash (Li and Shao, 2009), which could 


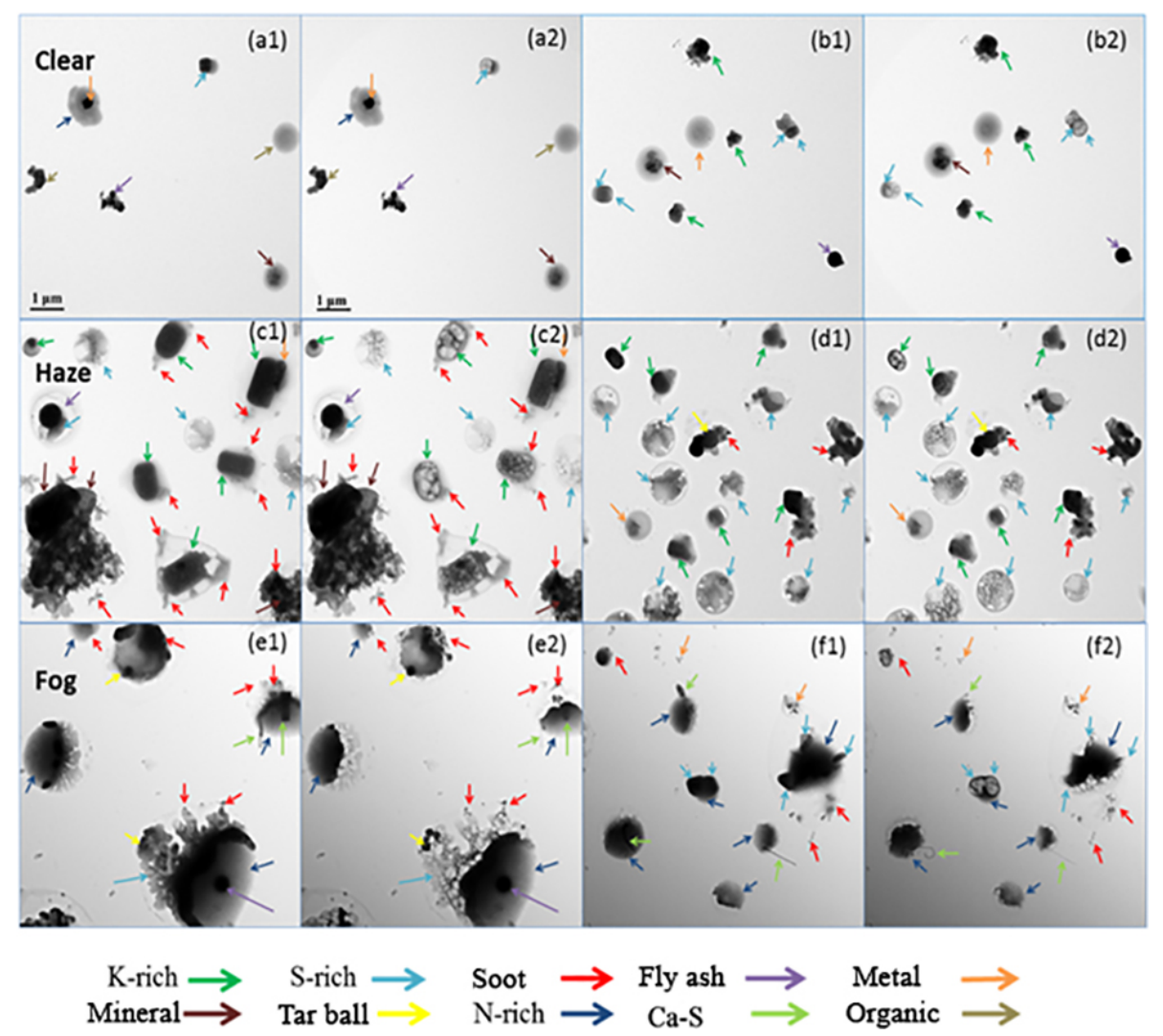

Figure 6. TEM typical views of the particles in clear (upper row), haze (middle row) and fog episodes (bottom row). Ten components are marked with the coloured arrows. Images (a1)-(f1) are obtained before the electron exposure and (a2)-(f2) are after exposure. A fraction of S-rich particles and other unstable particles decompose after electron exposure.

explain the results. Additionally, haze and fog episodes held a higher possibility of collision and attachment due to the heavy particle loading and prolonged their remaining in the atmosphere ( $\mathrm{Li}$ and Shao, 2009; $\mathrm{Li}$ et al., 2010), leading to a higher internal mixed-state percentage around $65 \%$.

\subsection{Optical properties related to morphological types of aerosols}

The different morphologies of the particles collected from the different weather can be easily identified under the TEM, as shown in Fig. 6. Due to the washout effect of the heavy rain, the particles collected in the typical clear period of EP2 were much smaller in size (Figs. 6a, b), which was in good agreement with the larger Angström exponent. Coarse particles, such as dusts, were hardly observed, whereas a few K-rich particles were detected, whose shapes were small and cubic. Such particles could be explained by the coal combustion around the sampling site due to the slight presence of fire spots. In addition, the cubic shape of K-rich particles suggested that they had not undergone long-range transportation or severe photochemical reaction because cubic K-rich particles were generally generated as a result of the molten nature of the material at high temperatures (Ault et al., 2012).
Likewise, soot was generally less oxidized in the EP-2 periods, maintaining fractional morphologies and external mixing. Small metal particles and amorphous $\mathrm{Zn}$ particles dominated the fine particles, which was ascribed to the industrial activity and/or waste incineration (Choël et al., 2006; Moffet et al., 2008).

In the EP-5 episode, the increased aerosol loading played a remarkable role in the enhancement of scattering coefficient and decrease in visibility (Kang et al., 2013; Charlson et al., 1987; Deng et al., 2008). Because of the high rate of aerosol collision, particles were larger than those on the clear days (Fig. 6c, d), leading to a smaller Ångström exponent. Almost all of the soot particles observed under the TEM were compact and adhesive. These were internally mixed with the Krich particles, which were larger, rounder or with a coating of high-S components. As discussed above, they were probably transported from the southern crop residual burning and had undergone aging in the atmosphere, which was confirmed by the trajectories passing through intense fire spots. Due to the high concentration of soot, EP-5 were characterized by a high absorption coefficient, shown in Fig. 3.

The $\mathrm{BC}$ variations in the different weather types during the sampling period are illustrated in Fig. 7. The prelimi- 


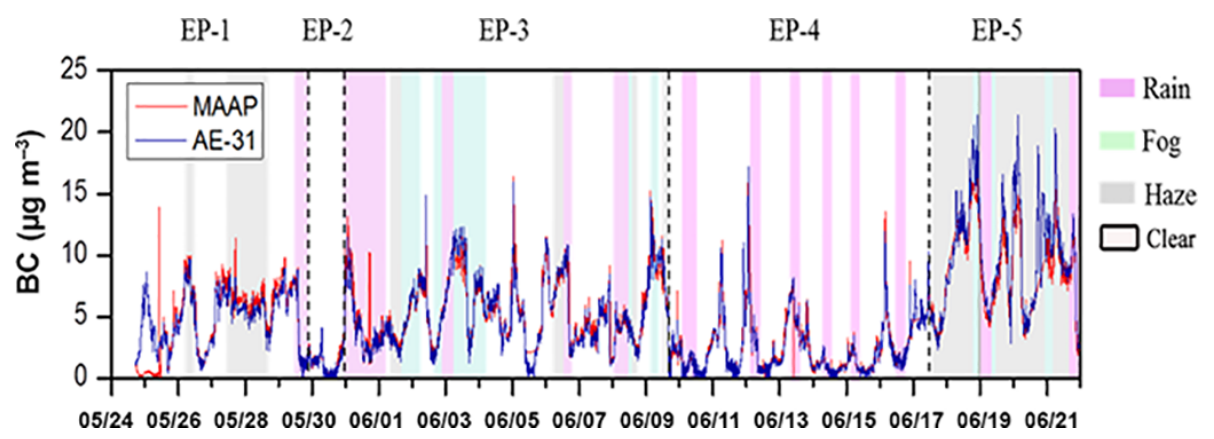

Figure 7. BC concentrations converted from the data measured by the AE-31 and MAAP. Good correlation is observed.

nary component of $\mathrm{BC}$ could be viewed as soot. High $\mathrm{BC}$ concentration was easily recognized in EP-5, with a mean value of $12.8 \mu \mathrm{g} \mathrm{m}^{-3}$, while it is low, up to $1.04 \mu \mathrm{g} \mathrm{m}^{-3}$, during the clear periods. The former is about 11.3 times higher than that of the latter, which is due to the lower boundary layer. In comparison, the absorption coefficient of EP$5\left(468.7 \mathrm{Mm}^{-1}\right)$ was about 94.7 times higher than that of EP-4 $\left(1.3 \mathrm{Mm}^{1}\right)$, more than 8 times the $\mathrm{BC}$ ratio. It was supposed that $\mathrm{BC}$ was internally mixed with other aerosols in the EP-5, which led to the considerable increase in absorption coefficient (Tan et al., 2016). However, models estimated an enhancement of BC forcing up to a factor of 2.9 when $\mathrm{BC}$ is internally mixed with other aerosols, compared with externally mixed scenarios (Jacobson, 2001), which was much lower than this case. Accordingly, other lightabsorbing substances may contribute to the discrepancy. For example, brown carbon is an indispensable component of biomass burning, which has a strong absorption ability as well (Hoffer et al., 2006; Andreae and Gelencsér, 2006). Other particles such as dust may also contribute to the overenhanced absorption coefficient (Yang et al., 2009). Our observations were agreement with the previous studies reported by (Wang et al., 2009b; Xia et al., 2006), which shows that aerosol particles under hazy weather conditions generate a positive heating effect on the atmosphere. During the foggy days of EP-3 episode, the high $\mathrm{PM}_{10}$ concentration and AOD caused a significant increase in scattering coefficient (Tan et al., 2016). Furthermore, metal-bearing particles and soot were internally associated with some coatings, including Srich, N-rich and K-rich particles. Zhang et al. (2008) reported that coating with sulfuric acid enhanced the optical properties of soot aerosols. Furthermore, the collected particles showed a larger size than those collected from the clear days under the TEM (Fig. 6e, f). The larger-sized particles on the foggy days could be caused by hydroscopic growth under the high relative humidity (Shingler et al., 2016), as well as the collision among the overloading particles, which was likewise illustrated by the Ångström exponent shown in Fig. 3. Consequently, the larger particles enhance the scattering of sunlight and lead to more apparent impairment of visibility (Quan et al., 2011). Chow et al. (2002) reported that RH also has a profound impact on visibility. Some fan-like nitrate particles have inclusions which may act as the growth cores or be encompassed during the hydroscopic growth. Bian et al. (2009) reported that whenever the $\mathrm{RH}$ is elevated, its importance to AOD is substantially amplified if the particles are hygroscopic (Bian et al., 2009). Li et al. (2010) found that soot particles became hydrophilic when they were coated with the water-soluble compounds such as sulfates or nitrates, implying that soot can provide important nuclei for the development of aerosol particles. Furthermore, Fig. 6e and f illustrate a large fraction of internally mixed soot. This was not visible until it was exposed to the electron beam for a short time. As for an internally mixed particle, sulfate and nitrate coatings act as a "focusing mirror" and enhance light absorption greatly. Therefore, the BC concentration in foggy conditions was $6.12 \mu \mathrm{g} \mathrm{m}^{3}$ and the absorption coefficient was $143.7 \mathrm{Mm}^{-1}$, which are 2.09 and 0.83 times greater than for the hazy days, respectively. Model calculations have also shown that the light absorption ability of the internally mixed soot particles was $30 \%$ higher than that of soot alone (Fuller et al., 1999). A variety of metal particles were also observed on the foggy days, as foggy days had a stable low upper layer boundary and weak wind, leading to the accumulation of pollution. These pollution sources range from steel plants and waste incineration to vehicle emission (Hu et al., 2015).

\section{Conclusions}

The relationship between characteristics of aerosol particles and optical properties is of importance to atmospheric chemistry research. However, the relationship between characteristics of aerosol particles and optical absorption remains poorly understood. Characteristics of aerosol optical properties, morphologies and their relationship were studied in urban Beijing during the clear, haze and fog episodes, sampled from 24 to 22 June 2012. A transmission electron microscope (TEM), a cavity ring-down spectrometer (CRDS), a nephelometer and an Aethalometer were employed to investigate the corresponding changes in aerosol properties. Five episodes were categorized according to the meteoro- 
logical conditions and composition. The results indicated that the clear episode (EP-2 and EP-4) was characterized by low aerosol optical depth $(\mathrm{AOD}=0.72)$ and fewer pollutants compared with haze (1.14) and fog (2.92) episodes, which are mostly externally mixed. The high Ångström exponent $(>2.0)$ suggests that coarse particles were scarcely observed in EP-2 due to the washout of a previous heavy rain, whereas they were widespread in EP-4 (Ångström exponent $=0.04$ ), which had some mineral particles introduced from the north. In contrast, industry-induced haze (EP-1) and biomass burning-induced haze (EP-5) were both affected by the south air mass. Higher AOD values illustrated heavy loading particle concentrations. All of the particles were classified into nine categories, i.e. S-rich, N-rich, mineral, Krich, soot, tar ball, organic, metal and fly ash, based on the TEM analysis. In the haze episode, as the influence of severe crop residue combustion, a large fraction of soot was detected, which sticks to sulfate or nitrate particles transformed from $\mathrm{KCl}$. Black carbon (BC) acceleration, internally mixed effects, and other light-absorbing substances contributed to the light absorption enhancement. For foggy days, soot was mostly internally mixed with sulfates and nitrates, which were visible after electron exposure under the TEM. The larger size distribution was likely to be caused by both hygroscopic growth and collision between particles during aging. About $28 \%$ of particles were internally mixed on the foggy days, which favoured light absorption. The comparison of all the episodes provides a deeper insight into how mixing states influence the aerosol extinction properties and also a clue as to how control air pollution in the crop burning seasons. The results presented herein are beneficial to air pollution control and prevention in China.

Competing interests. The authors declare that they have no conflict of interest.

Acknowledgements. This work was supported by the National Natural Science Foundation of China (no. 21577022, 21190053, 40975074), the Ministry of Science and Technology of China (2016YFC0202700), and the international cooperation project of Shanghai municipal government (15520711200).

Edited by: T. Zhu

Reviewed by: three anonymous referees

\section{References}

Adachi, K. and Buseck, P. R.: Internally mixed soot, sulfates, and organic matter in aerosol particles from Mexico City, Atmos. Chem. Phys., 8, 6469-6481, doi:10.5194/acp-8-6469-2008, 2008.
Adler, G., Riziq, A. A., Erlick, C., and Rudich, Y.: Effect of intrinsic organic carbon on the optical properties of fresh diesel soot, P. Natl. Acad. Sci. USA., 107, 6699-6704, 2010.

Alexander, D. T., Crozier, P. A., and Anderson, J. R.: Brown carbon spheres in East Asian outflow and their optical properties, Science, 321, 833-836, 2008.

Anderson, T.L. and Ogren, J. A.: Determining aerosol radiative properties using the TSI 3563 integrating nephelometer, Aerosol Air Qual. Res., 29, 57-69, 1998.

Andreae, M. O. and Gelencsér, A.: Black carbon or brown carbon? The nature of light-absorbing carbonaceous aerosols, Atmos. Chem. Phys., 6, 3131-3148, doi:10.5194/acp-6-3131-2006, 2006.

Ault A. P., Peters T. M., Sawvel E. J., Casuccio G. S., Willis R. D., Norris G. A., and Grassian, V. H.: Single-particle SEM-EDX analysis of iron-containing coarse particulate matter in an urban environment: sources and distribution of iron within Cleveland, Ohio, Environ. Sci. Technol., 46, 4331-4339, 2012.

Bahadur, R., Praveen, P. S., Xu, Y., and Ramanathan, V.: Solar absorption by elemental and brown carbon determined from spectral observations, P. Natl. Acad. Sci. USA., 109, 17366-17371, 2012.

Bian, H., Chin, M., Rodriguez, J. M., Yu, H., Penner, J. E., and Strahan, S.: Sensitivity of aerosol optical thickness and aerosol direct radiative effect to relative humidity, Atmos. Chem. Phys., 9, 2375-2386, doi:10.5194/acp-9-2375-2009, 2009.

Bond, T. C.: Spectral dependence of visible light absorption by carbonaceous particles emitted from coal combustion, Geophys. Res. Lett., 28, 4075-4078, 2001.

Brown, A. J.: Spectral bluing induced by small particles under the Mie and Rayleigh regimes, Lcarus, 239, 85-95, 2014.

Buseck, P. R., and POsfai, M.: Airborne minerals and related aerosol particles: Effects on climate and the environment, P. Natl. Acad. Sci. USA., 96, 3372-3379, 1999.

Carabali, G., Mamani-Paco, R., Castro, T., Peralta, O., Herrera, E., and Trujillo, B.: Optical properties, morphology and elemental composition of atmospheric particles at T1 supersite on MILAGRO campaign, Atmos. Chem. Phys., 12, 2747-2755, doi:10.5194/acp-12-2747-2012, 2012.

Chakrabarty, R. K., Moosmüller, H., Chen,L.-W. A., Lewis, K., Arnott, W. P., Mazzoleni, C., Dubey, M. K., Wold, C. E., Hao, W. M., and Kreidenweis, S. M.: Brown carbon in tar balls from smoldering biomass combustion, Atmos. Chem. Phys., 10, 63636370, doi:10.5194/acp-10-6363-2010, 2010.

Chameides, W. L., Yu, H., Liu, S., Bergin, M., Zhou, X., Mearns, L., Wang, G., Kiang, C., Saylor, R., and Luo, C.: Case study of the effects of atmospheric aerosols and regional haze on agriculture: An opportunity to enhance crop yields in China through emission controls?, P. Natl. Acad. Sci. USA, 96, 13626-13633, 1999.

Charlson, R. J., Lovelock, J. E., Andreae, M. O., and Warren, S. G.: Oceanic phytoplankton, atmospheric sulphur, cloud albedo and climate, Nature, 326, 655-661, 1987.

Che, H., Xia, X., Zhu, J., Li, Z., Dubovik, O., Holben, B., Goloub, P., Chen, H., Estelles, V., Cuevas-Agulló, E., Blarel, L., Wang, H., Zhao, H., Zhang, X., Wang, Y., Sun, J., Tao, R., Zhang, X., and Shi, G.: Column aerosol optical properties and aerosol radiative forcing during a serious haze-fog month over North China Plain in 2013 based on ground-based sunphotometer measure- 
ments, Atmos. Chem. Phys., 14, 2125-2138, doi:10.5194/acp14-2125-2014, 2014.

China, S., Mazzoleni, C., Gorkowski, K., Aiken, A. C., and Dubey, M. K.: Morphology and mixing state of individual freshly emitted wildfire carbonaceous particles, Nat. Commun., 4, 1-7, 2013.

Choël, M., Deboudt, K., Flament, P., Lecornet, G., Perdrix, E., and Sobanska, S.: Fast evolution of tropospheric $\mathrm{Pb}$-and $\mathrm{Zn}$-rich particles in the vicinity of a lead smelter, Atmos. Environ., 40, 44394449, 2006.

Chow, J. C., Bachmann, J. D., Wierman, S. S., Mathai, C., Malm, W. C., White, W. H., Mueller, P. K., Kumar, N., and Watson, J. G.: Visibility: science and regulation, J. Air. Waste Manage., 52, 973-999, 2002.

Clarke, A., McNaughton, C., Kapustin, V., Shinozuka, Y., Howell, S., Dibb, J., Zhou, J., Anderson, B., Brekhovskikh, V., and Turner, H.: Biomass burning and pollution aerosol over North America: Organic components and their influence on spectral optical properties and humidification response, J. Geophys. Res.Atmos., 112, 1-12, 2007.

Deng, X., Tie, X., Wu, D., Zhou, X., Bi, X., Tan, H., Li, F., and Jiang, C.: Long-term trend of visibility and its characterizations in the Pearl River Delta (PRD) region, China, Atmos. Environ., 42, 1424-1435, 2008.

Dey, S., Tripathi, S. N., Singh, R. P., and Holben, B. N.: Influence of dust storms on the aerosol optical properties over the Indo-Gangetic basin, J. Geophys. Res.-Atmos., 109, 1-10, doi:10.1029/2004jd004924, 2004.

Doran, J. C., Barnard, J. C., Arnott, W. P., Cary, R., Coulter, R., Fast, J. D., Kassianov, E. I., Kleinman, L., Laulainen, N. S., Martin, T., Paredes-Miranda, G., Pekour, M. S., Shaw, W. J., Smith, D. F., Springston, S. R., and Yu, X.-Y.: The T1-T2 study: evolution of aerosol properties downwind of Mexico City, Atmos. Chem. Phys., 7, 1585-1598, doi:10.5194/acp-7-1585-2007, 2007.

Duan, F., Liu, X., Yu, T., and Cachier, H.: Identification and estimate of biomass burning contribution to the urban aerosol organic carbon concentrations in Beijing, Atmos. Environ., 38, 1275-1282, 2004.

Ebert, M., Weinbruch, S., Hoffmann, P., and Ortner, H. M.: The chemical composition and complex refractive index of rural and urban influenced aerosols determined by individual particle analysis, Atmos. Environ., 38, 6531-6545, 2004.

Eck, T. F., Holben, B. N., Reid, J. S., Dubovik, O., Smirnov, A., O'Neill, N. T., Slutsker, I., and Kinne, S.: Wavelength dependence of the optical depth of biomass burning, urban, and desert dust aerosols, J. Geophys. Res.-Atmos., 104, 3133331349, doi:10.1029/1999jd900923, 1999.

Engling, G., Lee, J. J., Tsai, Y.-W., Lung, S.-C. C., Chou, C. C.K., and Chan, C.-Y.: Size-resolved anhydrosugar composition in smoke aerosol from controlled field burning of rice straw, Aerosol Air Qual. Res., 43, 662-672, 2009.

Fu, H., Zhang, M., Li, W., Chen, J., Wang, L., Quan, X., and Wang, W.: Morphology, composition and mixing state of individual carbonaceous aerosol in urban Shanghai, Atmos. Chem. Phys., 12, 693-707, doi:10.5194/acp-12-693-2012, 2012.

Fuller, K. A., Malm, W. C., and Kreidenweis, S. M.: Effects of mixing on extinction by carbonaceous particles, J. Geophys. Res.Atmos., 104, 15941-15954, 1999.

Guo, L., Hu, Y., Hu, Q., Lin, J., Li, C., Chen, J., Li, L., and Fu, H.: Characteristics and chemical compositions of particulate matter collected at the selected metro stations of Shanghai, China, Sci. Total Environ., 496, 443-452, 2014a.

Guo, Y., Feng, N., Christopher, S. A., Kang, P., Zhan, F. B., and Hong, S.: Satellite remote sensing of fine particulate matter $\left(\mathrm{PM}_{2.5}\right)$ air quality over Beijing using MODIS, Int. J. Remote Sens., 35, 6522-6544, 2014b.

Gustafsson, Ö., Kruså, M., Zencak, Z., Sheesley, R. J., Granat, L., Engström, E., Praveen, P., Rao, P., Leck, C., and Rodhe, H.: Brown clouds over South Asia: biomass or fossil fuel combustion?, Science, 323, 495-498, 2009.

Habib, G., Venkataraman, C., Bond, T. C., and Schauer, J. J.: Chemical, microphysical and optical properties of primary particles from the combustion of biomass fuels, Environ. Sci. Technol., 42, 8829-8834, 2008.

Hand, J. L., Malm, W., Laskin, A., Day, D., Lee, T.-b., Wang, C., Carrico, C., Carrillo, J., Cowin, J. P., and Collett, J.: Optical, physical, and chemical properties of tar balls observed during the Yosemite Aerosol Characterization Study, J. Geophys. Res.Atmos., 110, 1-8, 2005.

Hansen, A.: The Aethalometer Manual, Magee Sci., Berkeley, Calif, 2003.

Hoffer, A., Gelencsér, A., Guyon, P., Kiss, G., Schmid, O., Frank, G. P., Artaxo, P., and Andreae, M. O.: Optical properties of humic-like substances (HULIS) in biomass-burning aerosols, Atmos. Chem. Phys., 6, 3563-3570, doi:10.5194/acp-6-3563-2006, 2006.

Hu, Y., Lin, J., Zhang, S., Kong, L., Fu, H., and Chen, J.: Identification of the typical metal particles among haze, fog, and clear episodes in the Beijing atmosphere, Sci. Total Environ., 511, 369-380, 2015.

Hauglustaine, D. A., Balkanski, Y., and Schulz, M.: A global model simulation of present and future nitrate aerosols and their direct radiative forcing of climate, Atmos. Chem. Phys., 14, 1103111063, doi:10.5194/acp-14-11031-2014, 2014.

Jacobson, M. Z.: Strong radiative heating due to the mixing state of black carbon in atmospheric aerosols, Nature, 409, 695-697, 2001.

Jacobson, M. Z.: Control of fossil-fuel particulate black carbon and organic matter, possibly the most effective method of slowing global warming, J. Geophys. Res.-Atmos., 107, 1-9, 2002.

Jeong, C.-H., Hopke, P. K., Kim, E., and Lee, D.-W.: The comparison between thermal-optical transmittance elemental carbon and Aethalometer black carbon measured at multiple monitoring sites, Atmos. Environ., 38, 5193-5204, 2004.

Kang, H., Zhu, B., Su, J., Wang, H., Zhang, Q., and Wang, F.: Analysis of a long-lasting haze episode in Nanjing, China, Atmos. Res., 120, 78-87, 2013.

Katrinak, K. A., Rez, P., Perkes, P. R., and Buseck, P. R.: Fractal geometry of carbonaceous aggregates from an urban aerosol, Environ. Sci. Technol., 27, 539-547, 1993.

Khoder, M.: Atmospheric conversion of sulfur dioxide to particulate sulfate and nitrogen dioxide to particulate nitrate and gaseous nitric acid in an urban area, Chemosphere, 49, 675-684, 2002.

Kleinman, L. I., Daum, P. H., Lee, Y. N., Senum, G. I., Springston, S. R., Wang, J., Berkowitz, C., Hubbe, J., Zaveri, R. A., and Brechtel, F. J.: Aircraft observations of aerosol composition and ageing in New England and Mid-Atlantic States during the summer 2002 New England Air Quality Study field campaign, J. Geophys. Res.-Atmos., 112, 1-11, 2007. 
Krasowsky, T. S., McMeeking, G. R., Wang, D. B., Sioutas, C., and Ban-Weiss, G. A.: Measurements of the impact of atmospheric aging on physical and optical properties of ambient black carbon particles in Los Angeles, Atmos. Environ., 142, 496-504, 2016.

Lack, D. A., Langridge, J. M., Bahreini, R., Cappa, C. D., Middlebrook, A. M., and Schwarz, J. P.: Brown carbon and internal mixing in biomass burning particles, P. Natl. Acad. Sci. USA., 109, 14802-14807, doi:10.1073/pnas.1206575109, 2012.

Langridge, J. M., Lack, D., Brock, C. A., Bahreini, R., Middlebrook, A. M., Neuman, J. A., Nowak, J. B., Perring, A. E., Schwarz, J. P., and Spackman, J. R.: Evolution of aerosol properties impacting visibility and direct climate forcing in an ammonia-rich urban environment, J. Geophys. Res.-Atmos., 117, $1-17,2012$.

Lei, T., Zuend, A., Wang, W. G., Zhang, Y. H., and Ge, M. F.: Hygroscopicity of organic compounds from biomass burning and their influence on the water uptake of mixed organic ammonium sulfate aerosols, Atmos. Chem. Phys., 14, 11165-11183, doi:10.5194/acp-14-11165-2014, 2014.

Lewis, K., Arnott, W. P., Moosmüller, H., and Wold, C. E.: Strong spectral variation of biomass smoke light absorption and single scattering albedo observed with a novel dual-wavelength photoacoustic instrument, J. Geophys. Res.-Atmos., 113, 1-14, 2008.

Li, L., Chen, J. M., Chen, H., Yang, X., Tang, Y., and Zhang, R. Y.: Monitoring optical properties of aerosols with cavity ring-down spectroscopy, J. Aerosol Sci., 42, 277-284, 2011.

Li, W. and Shao, L.: Transmission electron microscopy study of aerosol particles from the brown hazes in northern China, J. Geophys. Res.-Atmos., 114, 1-10, 2009.

Li, C., Marufu, L. T., Dickerson, R. R., Li, Z., Wen, T., Wang, Y., Wang, P., Chen, H., and Stehr, J. W.: In situ measurements of trace gases and aerosol optical properties at a rural site in northern China during East Asian Study of Tropospheric Aerosols: An International Regional Experiment 2005, J. Geophys. Res.Atmos., 112, 1-16, 2007.

Li, J., Pósfai, M., Hobbs, P. V., and Buseck, P. R.: Individual aerosol particles from biomass burning in southern Africa: 2, Compositions and aging of inorganic particles, J. Geophys. Res.-Atmos., 108, 1-12, 2003.

Li, W. and Shao, L.: Characterization of mineral particles in winter fog of Beijing analyzed by TEM and SEM, Environ. Monit. Assess., 161, 565-573, 2010.

Li, W. J., Shao, L. Y., and Buseck, P. R.: Haze types in Beijing and the influence of agricultural biomass burning, Atmos. Chem. Phys., 10, 8119-8130, doi:10.5194/acp-10-8119-2010, 2010.

Moffet, R. C., Desyaterik, Y., Hopkins, R. J., Tivanski, A. V., Gilles, M. K., Wang, Y., Shutthanandan, V., Molina, L. T., Abraham, R. G., and Johnson, K. S.: Characterization of aerosols containing $\mathrm{Zn}, \mathrm{Pb}$, and $\mathrm{Cl}$ from an industrial region of Mexico City, Environ. Sci. Technol., 42, 7091-7097, 2008.

Moffet, R. C. and Prather, K. A.: In-situ measurements of the mixing state and optical properties of soot with implications for radiative forcing estimates, P. Natl. Acad. Sci. USA., 106, 1187211877, 2009.

Pathak, R. K., Yao, X., and Chan, C. K.: Sampling artifacts of acidity and ionic species in $\mathrm{PM}_{2.5}$, Environ. Sci. Technol., 38, 254 259, 2004

Peppler, R., Bahrmann, C., Barnard, J. C., Laulainen, N., Turner, D., Campbell, J., Hlavka, D., Cheng, M., Ferrare, R., and Halthore,
R.: ARM Southern Great Plains site observations of the smoke pall associated with the 1998 Central American fires, B. Am. Meteorol. Soc., 81, 2563-2591, 2000.

Qian, Y., Wang, W., Leung, L. R., and Kaiser, D. P.: Variability of solar radiation under cloud-free skies in China: The role of aerosols, Geophys. Res. Lett., 34, 1-5, 2007.

Quan, J., Zhang, Q., He, H., Liu, J., Huang, M., and Jin, H.: Analysis of the formation of fog and haze in North China Plain (NCP), Atmos. Chem. Phys., 11, 8205-8214, doi:10.5194/acp-11-82052011, 2011.

Ram, K., Sarin, M., and Tripathi, S.: Temporal trends in atmospheric $\mathrm{PM}_{2.5}, \mathrm{PM}_{10}$, elemental carbon, organic carbon, watersoluble organic carbon, and optical properties: impact of biomass burning emissions in the Indo-Gangetic Plain, Environ. Sci. Technol., 46, 686-695, 2012.

Ramana, M., Ramanathan, V., Feng, Y., Yoon, S., Kim, S., Carmichael, G., and Schauer, J.: Warming influenced by the ratio of black carbon to sulphate and the black-carbon source, Nat. Geosci., 3, 542-545, 2010.

Ramanathan, V., Crutzen, P. J., Lelieveld, J., Mitra, A., Althausen, D., Anderson, J., Andreae, M., Cantrell, W., Cass, G., and Chung, C.: Indian Ocean Experiment: An integrated analysis of the climate forcing and effects of the great Indo-Asian haze, 2001.

Ramanathan, V., Chung, C., Kim, D., Bettge, T., Buja, L., Kiehl, J., Washington, W., Fu, Q., Sikka, D., and Wild, M.: Atmospheric brown clouds: Impacts on South Asian climate and hydrological cycle, P. Natl. Acad. Sci. USA., 102, 5326-5333, 2005.

Ramanathan, V., Ramana, M. V., Roberts, G., Kim, D., Corrigan, C., Chung, C., and Winker, D.: Warming trends in Asia amplified by brown cloud solar absorption, Nature, 448, 575-578, 2007.

Roden, C. A., Bond, T. C., Conway, S., and Pinel, A. B. O.: Emission factors and real-time optical properties of particles emitted from traditional wood burning cookstoves, Environ. Sci. Technol., 40, 6750-6757, 2006.

Saleh, R., Adams, P. J., Donahue, N. M., and Robinson, A. L.: The interplay between assumed morphology and the direct radiative effect of light-absorbing organic aerosol, Geophys. Res. Lett. 43, 8735-8743, 2016.

Seinfeld, J. H. and Pandis, S. N.: Atmospheric chemistry and physics: from air pollution to climate change, John Wiley \& Sons, 2012.

Shi, Z., Shao, L., Jones, T. P., Whittaker, A., Lu, S., Berube, K. A., He, T., and Richards, R. J.: Characterization of airborne individual particles collected in an urban area, a satellite city and a clean air area in Beijing, 2001, Atmos. Environ., 37, 4097-4108, 2003.

Shi, Z. B., Zhang, D. Z., Ji, H. Z., Hasegawa, S., and M., Hayashi.: Modification of soot by volatile species in an urban atmosphere, Sci. Total Environ., 389, 195-201, 2008.

Shingler, T., Sorooshian, A., Ortega, A., Crosbie, E., Wonaschütz, A., and Perring, A. E.: Ambient observations of hygroscopic growth factor and $\mathrm{f}(\mathrm{RH})$ below 1: Case studies from surface and airborne measurements, J. Geophys. Res., 121, 13661-13677, 2016.

Solomon, S.: Climate change 2007-the physical science basis: Working group I contribution to the fourth assessment report of the IPCC, Cambridge University Press, 2007.

Stanmore, B., Brilhac, J., and Gilot, P.: The oxidation of soot: a review of experiments, mechanisms and models, Carbon, 39, 2247-2268, 2001. 
Sun, Y., Zhuang, G., Tang, A., Wang, Y., and An, Z.: Chemical characteristics of $\mathrm{PM}_{2.5}$ and $\mathrm{PM}_{10}$ in haze-fog episodes in Beijing, Environ. Sci. Technol., 40, 3148-3155, 2006.

Takemura, T., Nakajima, T., Dubovik, O., Holben, B. N., and Kinne, S.: Single-scattering albedo and radiative forcing of various aerosol species with a global three-dimensional model, J. Climate., 15, 333-352, 2002.

Tan, H. B., Liu, L., Fan, S. J., Li, F., Yin, Y., Cai, M. F., and Chan, P. W.: Aerosol optical properties and mixing state of black carbon in the Pearl River Delta, China, Atmos. Environ., 131, 196-208, 2016.

Wang, G., Kawamura, K., Xie, M., Hu, S., Cao, J., An, Z., Waston, J. G., and Chow, J. C.: Organic molecular compositions and size distributions of Chinese summer and autumn aerosols from Nanjing: Characteristic haze event caused by wheat straw burning, Environ. Sci. Technol., 43, 6493-6499, 2009a.

Wang, H., He, C., Morawska, L., McGarry, P., and Johnson, G.: Ozone-initiated particle formation, particle aging, and precursors in a laser printer, Environ. Sci. Technol., 46, 704-712, $2012 \mathrm{a}$.

Wang, R., Tao, S., Wang, W., Liu, J., Shen, H., Shen, G., Wang, B., Liu, X., Li, W., and Huang, Y.: Black carbon emissions in China from 1949 to 2050, Environ. Sci. Technol., 46, 7595-7603, 2012b.

Wang, X. and Chen, J.: Fog formation in cold season in Ji'nan, China: case analyses with application of HYSPLIT model, Adv. Meteorol., 8, 1-9, 2014.

Wang, X., Xu, B., and Ming, J.: An overview of the studies on black carbon and mineral dust deposition in snow and ice cores in East Asia, J. Meteorol. Res., 28, 354-370, doi:10.1007/s13351-0144005-7, 2014.

Wang, Y., Zhuang, G., Sun, Y., and An, Z.: The variation of characteristics and formation mechanisms of aerosols in dust, haze, and clear days in Beijing, Atmos. Environ., 40, 6579-6591, 2006.
Wang, Y., Che, H., Ma, J., Wang, Q., Shi, G., Chen, H., Goloub, P., and Hao, X.: Aerosol radiative forcing under clear, hazy, foggy, and dusty weather conditions over Beijing, China, Geophys. Res. Lett., 36, 1-9, 2009 b.

Wu, D., Mao, J., Deng, X., Tie, X., Zhang, Y., Zeng, L., Li, F., Tan, H., Bi, X., and Huang, X.: Black carbon aerosols and their radiative properties in the Pearl River Delta region, Sci. China Ser. D, 52, 1152-1163, 2009.

Xia, X., Chen, H., Wang, P., Zhang, W., Goloub, P., Chatenet, B., Eck, T., and Holben, B.: Variation of column-integrated aerosol properties in a Chinese urban region, J. Geophys. Res.-Atmos., 111, 1-5, 2006.

Yan, P., Tang, J., Huang, J., Mao, J. T., Zhou, X. J., Liu, Q., Wang, Z. F., and Zhou, H. G.: The measurement of aerosol optical properties at a rural site in Northern China, Atmos. Chem. Phys., 8, 2229-2242, doi:10.5194/acp-8-2229-2008, 2008.

Yang, M., Howell, S. G., Zhuang, J., and Huebert, B. J.: Attribution of aerosol light absorption to black carbon, brown carbon, and dust in China - interpretations of atmospheric measurements during EAST-AIRE, Atmos. Chem. Phys., 9, 2035-2050, doi:10.5194/acp-9-2035-2009, 2009.

Yu, X., Cheng, T., Chen, J., and Liu, Y.: A comparison of dust properties between China continent and Korea, Japan in East Asia, Atmos. Environ., 40, 5787-5797, 2006.

Zhang, R., Khalizov, A. F., Pagels, J., Zhang, D., Xue, H., and McMurry, P. H.: Variability in morphology, hygroscopicity, and optical properties of soot aerosols during atmospheric processing, P. Natl. Acad. Sci. USA., 105, 10291-10296, 2008.

Zhang, W., Zhuang, G., Guo, J., Xu, D., Wang, W., Baumgardner, D., Wu, Z., and Yang, W.: Sources of aerosol as determined from elemental composition and size distributions in Beijing, Atmos. Res., 95, 197-209, doi:10.1016/j.atmosres.2009.09.017, 2010. 